\title{
An overview of high thermal conductive hot press forming die material development
}

\author{
A.R. Zulhishamuddin ${ }^{1}$ and S.N. Aqida ${ }^{1^{*}}$ \\ ${ }^{1}$ Faculty of Mechanical Engineering, University Malaysia Pahang \\ 26600 Pekan, Pahang, Malaysia \\ *Email: aqida@ump.edu.my \\ Phone : +609-424-6280; Fax : +609-424-6222
}

\begin{abstract}
Most of the automotive industries are using high strength steel components, which are produced via hot press forming process. This process requires die material with high thermal conductivity that increases cooling rate during simultaneous quenching and forming stage. Due to the benefit of high quenching rate, thermal conductive die materials were produced by adding carbide former elements. This paper presents an overview of the modification of alloying elements in tool steel for high thermal conductivity properties by transition metal elements addition. Different types of manufacturing processes involved in producing high thermal conductive materials were discussed. Methods reported were powder metallurgy hot press, direct metal deposition, selective laser melting, direct metal laser sintering and spray forming. Elements likes manganese, nickel, molybdenum, tungsten and chromium were proven to increase thermal conductivity properties. Thermal conductivity properties resulted from carbide network presence in the steel microstructure. To develop feasible and low cost hot press forming die material, casting of Fe-based alloy with carbide former composition can be an option. Current thermal conductivity properties of hot press forming die material range between 25 and $66 \mathrm{~W} / \mathrm{m} . \mathrm{K}$. The wide range of thermal conductivity varies the mechanical properties of the resulting components and lifetime of HPF dies.
\end{abstract}

Keywords: Hot press forming; thermal conductivity; tool steel; die; carbide.

\section{INTRODUCTION}

Hot press forming involves deformation of austenitised boron steel blank with simultaneous quenching process into required parts or components for high strength and hardness properties [1, 2]. To gain the high strength components, HPF die material thermal properties is significant to allow high quenching rate. To date, many studies have been conducted on die design, cooling channel geometry effects on component properties, stress analysis of pressed blank material and friction of blank coating materials [1-4]. High strength components produced by HPF exhibit a fully martensitic structure through cooling rate of $27^{\circ} \mathrm{C} / \mathrm{s}$ [5]. To allow this, HPF die material requires high thermal conductivity properties. Figure 1 shows the resulting hardness properties of boron steel at different cooling rates due to continuous cooling transformation. Hardness properties increase at increasingg cooling rate of $0.2^{\circ} \mathrm{C} / \mathrm{s}$ to $100^{\circ} \mathrm{C} / \mathrm{s}$. At $30^{\circ} \mathrm{C} / \mathrm{s}$, the hardness is 474 $\mathrm{HV}_{(0.1)}$, which is relative to approximately $1,520 \mathrm{MPa}$ tensile strength. Thus, tailoring the HPF die thermal conductivity properties through alloying element design along with HPF process parameters optimisation can vary the automotive components properties. Lower 
thermal conductivity dies utilisation delayed the forming process and led to longer cycle time, which increased production cost [6].

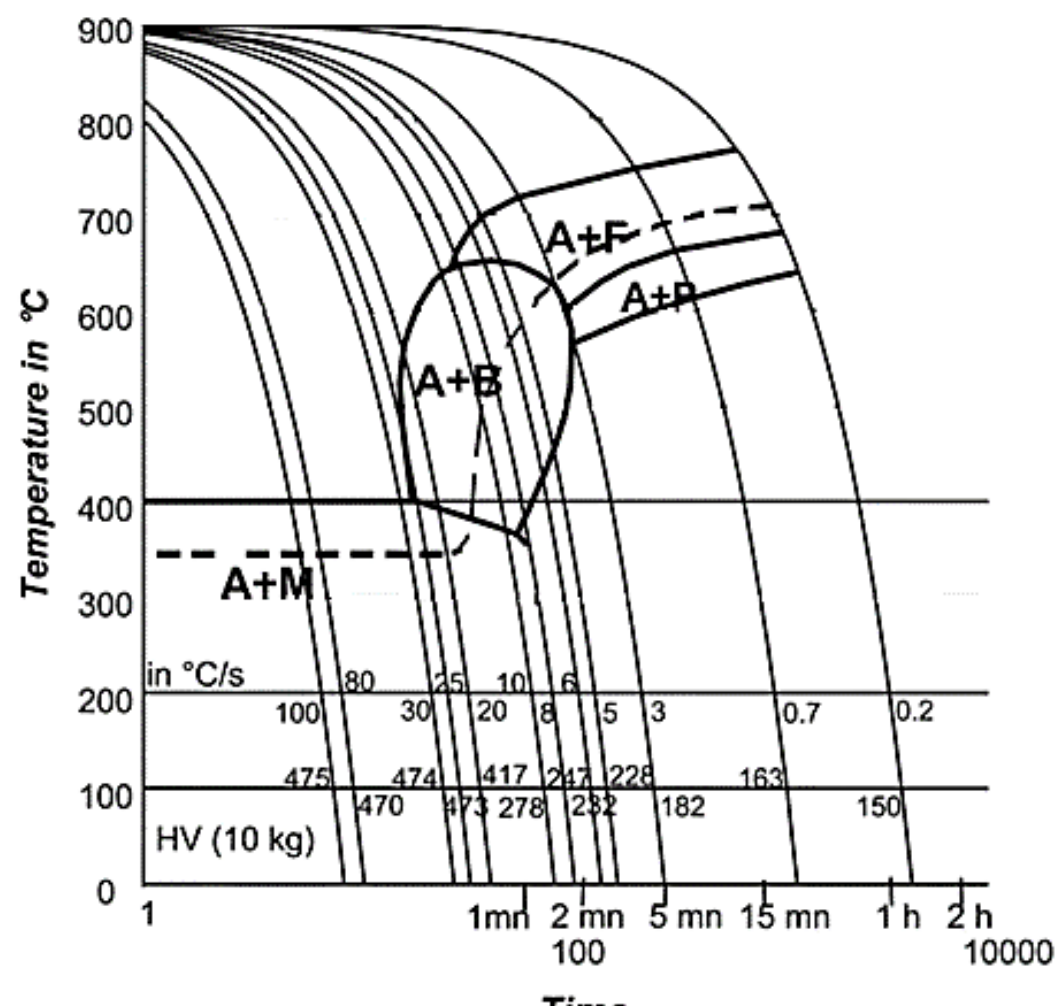

Time

Figure 1. Continuous cooling transformation diagram of $22 \mathrm{MnB} 5$, where $\mathrm{A}=$ austenite, $\mathrm{B}=$ bainite, $\mathrm{F}=$ ferrite, $\mathrm{P}=$ pearlite, $\mathrm{M}=$ martensitic [7].

Previous researchers have proven that high cooling rate during quenching is important in HPF process which required optimisation of cooling channel design in HPF die using finite element analysis [1, 2]. Furthermore, high heat transfer rate in HPF depends on several factors, such as the heat transfer from the blank material to the die surface and heat conductivity between cooling channel and die surface, and heat transfer from the die surface to the quenching medium in die cooling channel [5]. Few reports were found on modification of alloying element in HPF die materials for high thermal conductivity properties. This paper discussed current processes to produce HPF dies and possible modification of Fe-based alloys for high thermal conductivity properties by direct addition of transition metal alloying elements at different compositions.

\section{HPF DIE MANUFACTURING PROCESS}

Nowadays, various types of automotive component material had been produced to cater to customers' need for low production cost, economical energy, environmentally friendly process, lightweight, and the most important thing is higher in strength [8]. From 1975 until today, various types of material for automotive parts had been produced from microalloyed steels until material 22MnB5 [9]. Figure 2 shows the time horizon of steel development in the automotive industry in the last 30 years. Boron alloys of $22 \mathrm{MnB} 5$, $27 \mathrm{MnCrB5}$, and $37 \mathrm{MnB} 4$ steel grades are the only steel grades which produce a fully 
martensitic microstructure after hot press forming when a water cooled tool is used. Here, $22 \mathrm{MnB} 5$ steel grade is the most commonly used steel grade in hot press forming processes [5]. Because of the rapid development of new material, tool steel for the die material need to be improved to prevent from start breaking in the press because it cannot stand up to a new material [10]. It means that the development of new material for automotive part must be done together with the development of material for tool and die to avoid an increment in production cost .

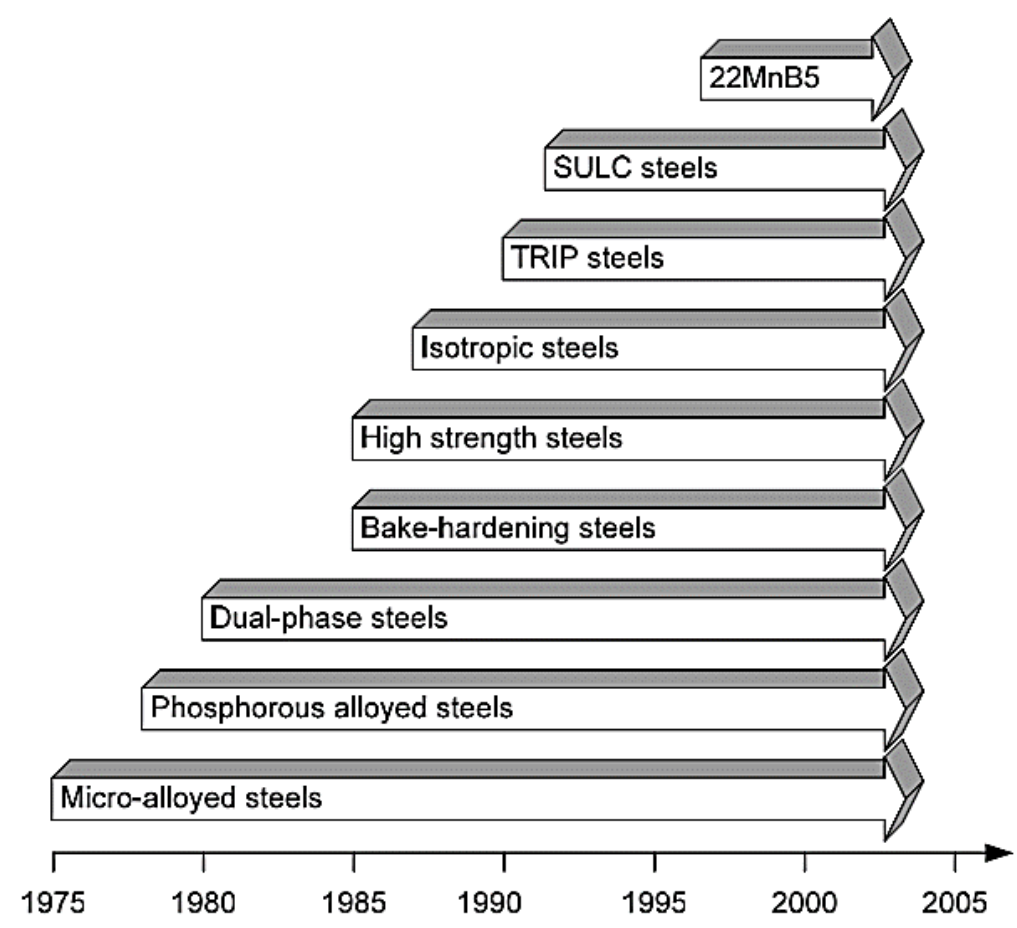

Figure 2. Time horizon of steel development in the automotive industry in the last 30 years [9].

Two issues need to be considered while selecting the materials for tool and die, firstly from design view (ductility, toughness, fatigue strength, wear resistance and corrosion resistance) and secondly from manufacturing view (hardness, machinability, polishability and dimensional stability) [10]. Both factors can increase the tool and die's life and can avoid the tool and die from failure, whilst reducing the cost of repairing. In the hot press forming process, except for these factors, thermal conductivity in material for tool and die is important to reduce thermal fatigue that is caused by the application of repetitive heating and cooling cycles apart from general mechanical loading. Other than that, hot press forming die experienced wear on the surface. This occurs due to the interactions between the die surface and blank [10]. The important group of tool steel is hot work tool steel. Hot work tool steels are divided into three classes, namely chromium base H10-H19, tungsten base $\mathrm{H} 20-\mathrm{H} 39$ and molybdenum base H40-H59, according to their principal alloying elements [11]. Note that the chromium containing grades are less expensive than the tungsten and molybdenum grades. They serve well at elevated temperatures. All these tool steels are high grade alloys as they have high element composition such as chromium, molybdenum, vanadium and silicon. 


\section{MODIFICATION OF DIE MATERIAL}

In general, die materials are made up from composition of metal element such as iron, chromium and carbon. Each of these elements has different levels of conductivity. For pure elements, the conductivity value is higher compared to the alloyed elements. For example, the pure iron at the temperature of $25^{\circ} \mathrm{C}$ has a thermal conductivity of 80 $\mathrm{W} / \mathrm{m} . \mathrm{K}$, while wrought iron $59 \mathrm{~W} / \mathrm{m} . \mathrm{K}$ and cast iron has the thermal conductivity 55 $\mathrm{W} / \mathrm{m} . \mathrm{K} .[12]$. This happened when the electrons are scattered in the alloyed metal structure. Scattered electrons are usually caused by impurity of atoms or fine particles which are dispersed in the atom. Figure 3 shows the effect of zinc composition on thermal conductivity of copper-zinc alloys [13]. Addition of zinc composition of $30 \mathrm{wt} \%$ decreased the thermal conductivity of the alloy by more than half.

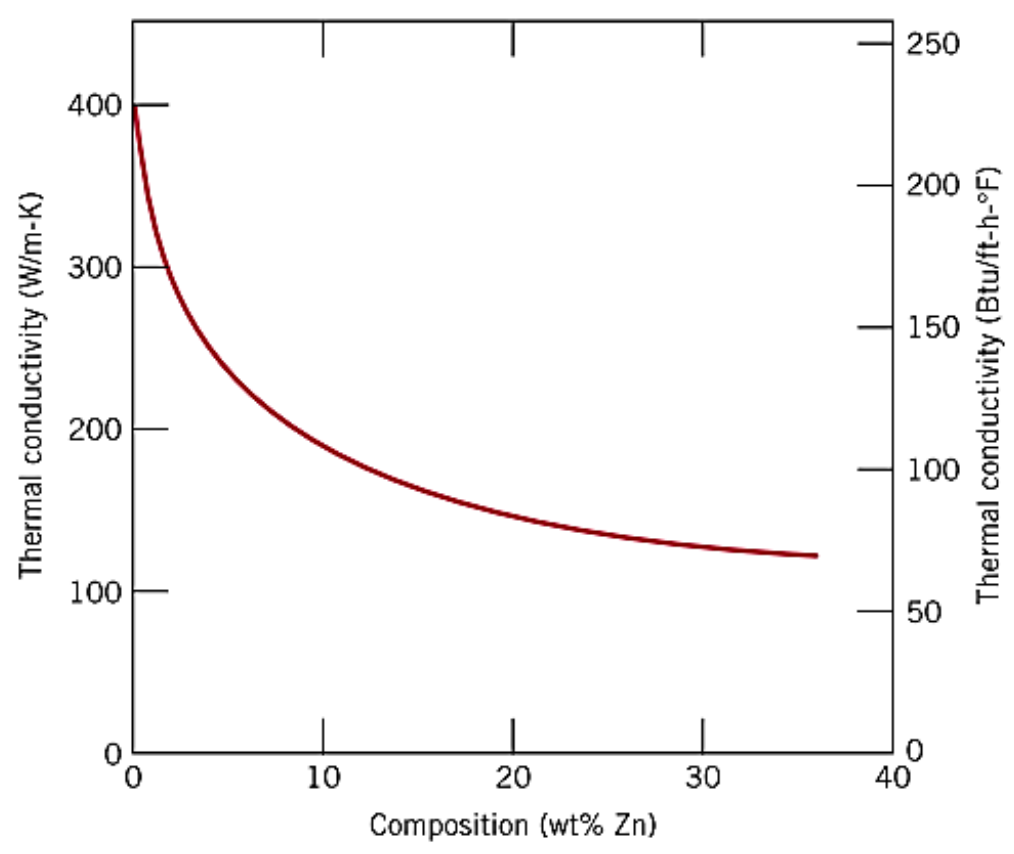

Figure 3. Thermal conductivity of copper-zinc alloys as a function of zinc composition [13].

Modification of the alloying composition in conventional alloy is a way to improve the mechanical and thermal properties of die materials. Thermal conductivity of an alloy depends on temperature and microstructure. When temperature decreases, thermal conductivity diverges. Meanwhile, increasing fraction of non-metallic inclusions and precipitated primary carbides resulted in a higher thermal conductivity steel. Pure iron has the highest thermal conductivity, followed by carbon steels, alloy steel and high alloy steels [14]. Peet et al. [14] observed that manganese, nickel, molybdenum and chromium have strong significance on increasing the thermal conductivity of steel. Their presence in stainless steel differed at varied compositions.

In Thyrotherm 2999 or Thermodur 2999, extra fine structure (EFS) high percentage of molybdenum was the main factor of its high thermal conductivity [15]. Thyrotherm 2999 steel was developed specifically for forging industry with high strength and wear resistant at elevated temperatures in combination with high thermal conductivity. At a wide range of temperature, Thyrotherm 2999 shows thermal conductivity almost constant 
compared to other modified steels. Different percentage alloying with molybdenum contributes towards the increase in the thermal conductivity properties of $\mathrm{H} 13$. At $5 \%$ molybdenum content, Thyrotherm 2999 steel produced high thermal conductivity in comparison to $3 \%$ content of molybdenum. These attributes make it applicable for die casting applications. Comparison of thermal conductivity as a function of testing temperature for as-received AISI H10 and H13 tool steel, and molybdenum modified tool steels is shown in Figure 4.

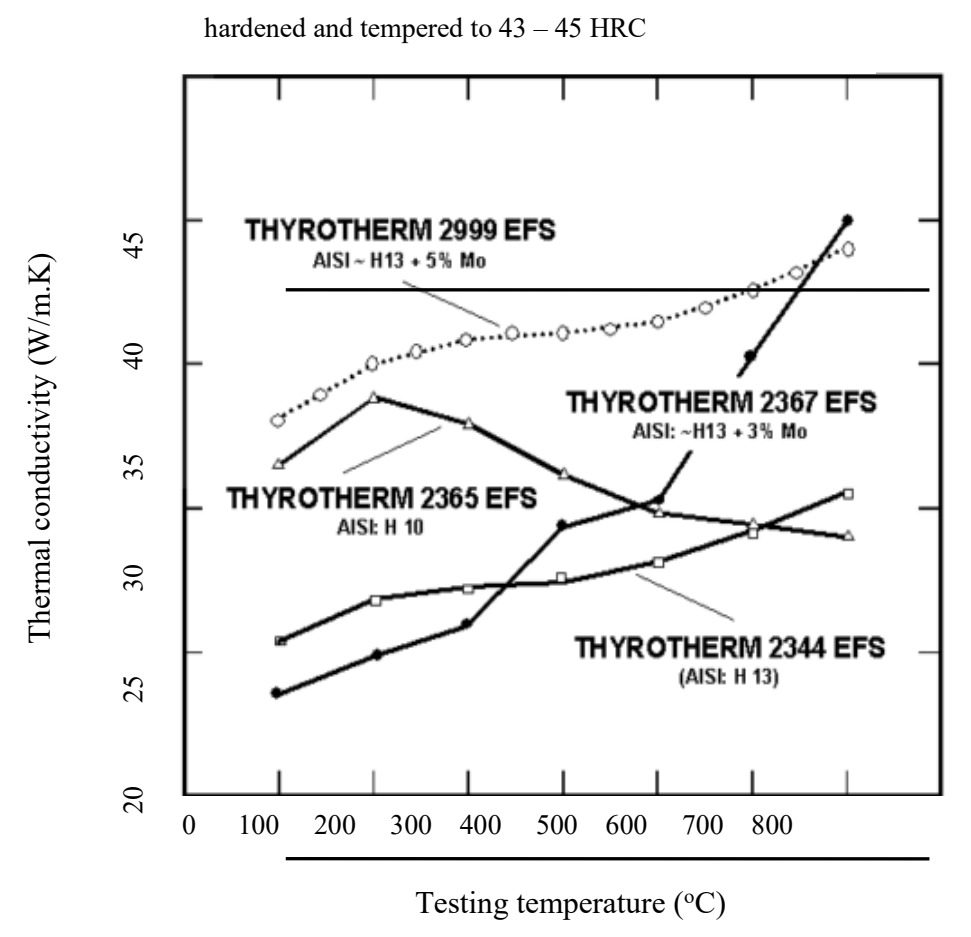

Figure 4. Thermal conductivity of as-received and molybdenum modified hot work tool steels [15].

In Figure 5, the significance of alloying elements in steel thermal conductivity is given by the bar chart. The highest significance was observed in manganese, nickel, molybdenum, and chromium. Carbon, silicon, vanadium and copper had a lower significance, while elements like titanium, tungsten, niobium and aluminium all had very low significance. The presence of cobalt and sulphur does not show static value, hence it is not significant for a good thermal conductivity[14]. This can be shown in Figure 5.

Thermal conductivity for conventional hot work tool steel like AISI H13 is 28 $\mathrm{W} / \mathrm{m}$.K while for high thermal conductivity steel (HTCS) from company Rovalma, Spain can be as high as $66 \mathrm{~W} / \mathrm{m} . \mathrm{K}$. The basic alloying elements in HTCS tool steel as in H13 varies in composition of carbon, molybdenum, vanadium, manganese, silicon, nickel and chromium [16]. In HTCS, additional alloying elements such as cobalt, tungsten and carbide forming elements of titanium, zirconium, hafnium and niobium were found [17]. These elements have high melting temperature, which formed carbide network in the alloy. The interfacial carbide in alloys increased the heat transmission in it [18-20]. The HTCS alloys were manufactured through powder press method that uses nanomaterial technology composed of processes like mixing, binding, compressing and sintering [1821]. This powder metallurgy method can produce near net shape alloys with high quality grade, composition and different properties at various locations [22]. Carbide former 
alloying elements have major contribution to the enhancement of thermal conductivity in die material. Elements like tungsten with high melting temperature and density is among good alloying element candidates to enhance the thermal properties. However, in conventional casting method, tungsten is not possible to be melted and can cause defects such as high segregation and porosity. The next section will present current processes to modify the thermal properties of tool steel.

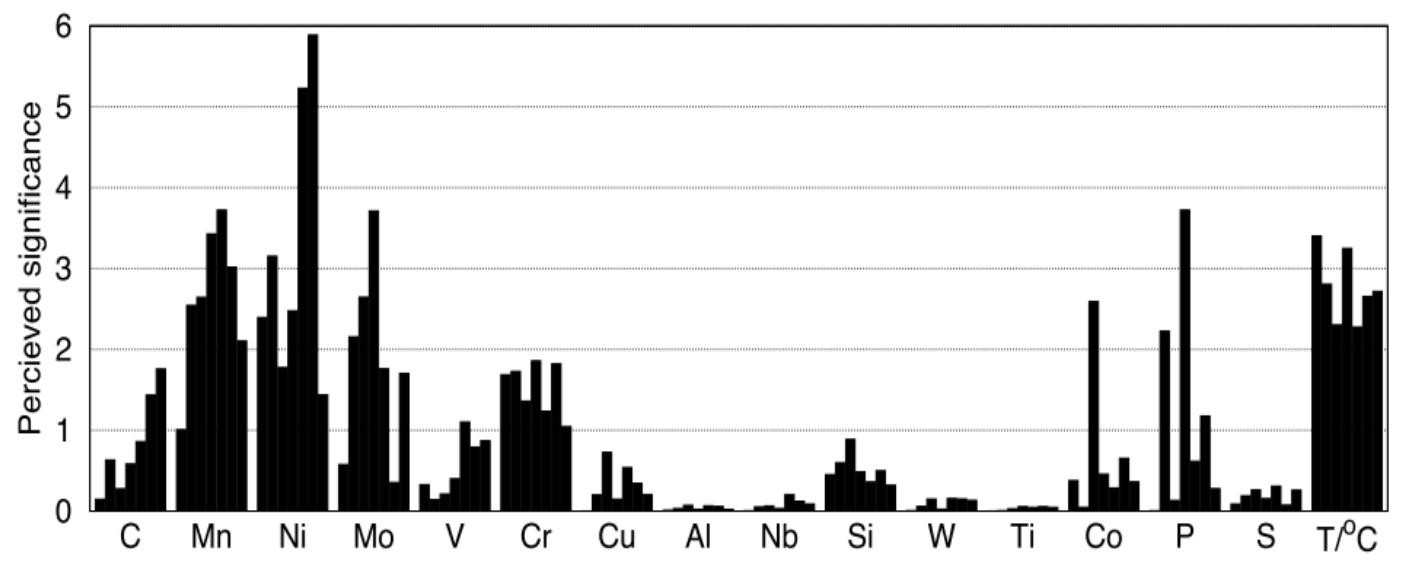

Figure 5. Significances of element to thermal conductivity properties of steel [14].

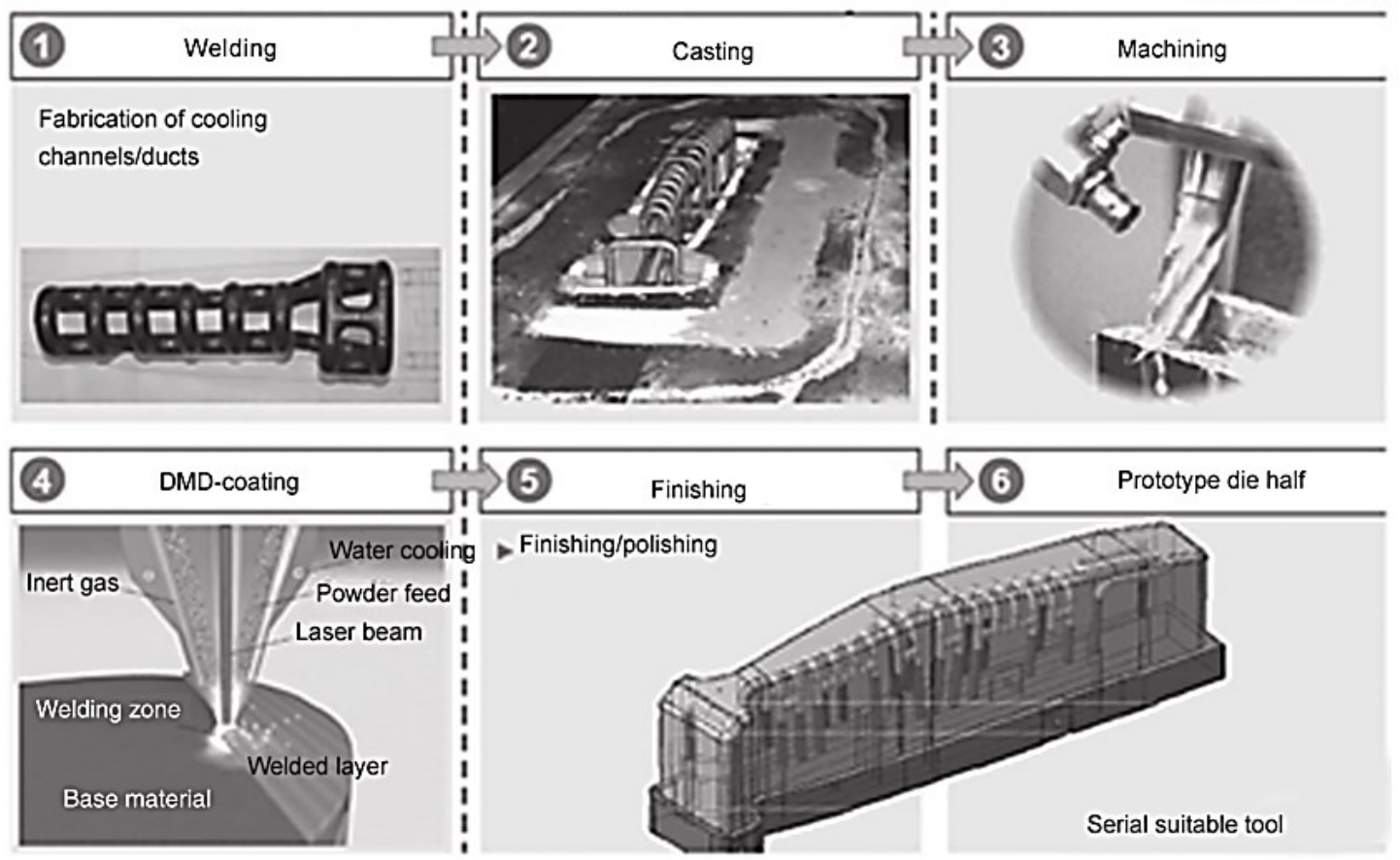

Figure 6. Casting of cooling ducts with direct metal deposition (DMD) technique [7].

\section{DEVELOPMENT OF HIGH THERMAL CONDUCTIVITY DIE MATERIAL}

Many researches have been conducted to improve die properties. Some of the methods are direct metal deposited (DMD), cast alloy with new composition, selective laser melting (SLM), direct metal laser sintering (DMLS), spray forming and powder 
metallurgy hot press [21, 23-27]. Table 1 outlines several works on the modification of thermal properties of different alloys using different techniques. Among these methods, cast alloy is excessively used to obtain the new feature in die because of its feasibility and lower cost than laser processing and powder metallurgy. Furthermore, casting is the best method to produce cooling channel within die. Cast alloys improved the cooling channel performance of tool and reduced the overall process cycle time [7]. In DMD technique, cooling channel is fabricated to a near perfect shape. Then, the fabricated cooling ducts are cast into gray cast iron or ductile graphite iron and the last step is using direct metal deposition technology, the tool surface is deposited with hard materials to improve wear resistance. Figure 6 shows the steps in casting cooling ducts with direct metal deposition (DMD) technique [7].

Table 1. Previous work on improvement of thermal properties of alloys.

\begin{tabular}{|c|c|c|c|}
\hline Methods & Purpose & Description & Reference \\
\hline $\begin{array}{l}\text { Direct } \\
\text { metal } \\
\text { deposited } \\
(\mathrm{DMD})\end{array}$ & $\begin{array}{l}\text { To enhance thermal } \\
\text { conductivity of } \mathrm{Al}-4 \mathrm{Cu}-1 \mathrm{Mg} \\
\text { alloy by depositing } 80 \mathrm{Cu}- \\
20 \mathrm{Mo}\end{array}$ & $\begin{array}{l}\text { This method is a surface } \\
\text { modification using laser } \\
\text { processing to improve } \\
\text { thermal conductivity of die. }\end{array}$ & {$[28]$} \\
\hline $\begin{array}{l}\text { Selective } \\
\text { laser } \\
\text { melting } \\
\text { (SLV) }\end{array}$ & $\begin{array}{l}\text { To fabricate of bi-metallic } \\
\text { parts using two materials: } \\
\text { Copper and H13. }\end{array}$ & $\begin{array}{l}\text { This method successfully } \\
\text { bonds using laser } \\
\text { processing and improves } \\
\text { the tensile strength and } \\
\text { hardness. }\end{array}$ & [25] \\
\hline $\begin{array}{l}\text { Direct } \\
\text { metal laser } \\
\text { sintering } \\
\text { (DMLS) }\end{array}$ & $\begin{array}{l}\text { To modify surface of } \mathrm{H} 13 \text { by } \\
\text { alloying with Fe-Ni-Cr } \\
\text { powder. }\end{array}$ & $\begin{array}{l}\text { This method can be used to } \\
\text { repair die surface by laser } \\
\text { processing. It can increase } \\
\text { the hardness of the H13 } \\
\text { surface. }\end{array}$ & [26] \\
\hline $\begin{array}{l}\text { Spray } \\
\text { forming }\end{array}$ & $\begin{array}{l}\text { To develop a new steel with } \\
\text { homogenous microstructure } \\
\text { and excellent cast properties }\end{array}$ & $\begin{array}{l}\text { This technology used } \\
\text { powder metallurgy to } \\
\text { directly transform a liquid } \\
\text { melt into solid material. }\end{array}$ & {$[27,29]$} \\
\hline $\begin{array}{l}\text { Powder } \\
\text { metallurgy } \\
\text { hot press }\end{array}$ & $\begin{array}{l}\text { To develop HTCS with high } \\
\text { thermal conductivity } \\
\text { properties }\end{array}$ & $\begin{array}{l}\text { This methods using hot } \\
\text { press to compacted powder } \\
\text { metal to develop a tool } \\
\text { steel. }\end{array}$ & [17] \\
\hline $\begin{array}{l}\text { Cast alloy } \\
\text { with new } \\
\text { composition }\end{array}$ & $\begin{array}{l}\text { To improve thermal } \\
\text { properties of } \mathrm{Mg}-\mathrm{Zn} \text { based } \\
\text { alloys }\end{array}$ & $\begin{array}{l}\text { This method uses casting } \\
\text { process to develop alloy } \\
\text { material. Adding Mn } \\
\text { significantly affected the } \\
\text { thermal conductivity. }\end{array}$ & [24] \\
\hline
\end{tabular}

\section{CONCLUSIONS}

In hot press forming process, simultaneous forming and high rate quenching is the key to obtaining high strength steel components. Conventional hot work tool steel used in HPF dies has lower thermal conductivity properties of $27 \mathrm{~W} / \mathrm{m} \cdot \mathrm{K}$. Meanwhile, recent die material like Rovalma HTCS-150 exhibits thermal conductivity of $66 \mathrm{~W} / \mathrm{m} \cdot \mathrm{K}$. The vast 
difference between minimum and maximum range of thermal conductivity determines the efficiency of HPF process and high strength components produced. High thermal conductive HPF die material produced high cooling rate of $27^{\circ} \mathrm{C} / \mathrm{s}$, which allows martensitic transformation to occur in component material. In order to produce high thermal conductive die material, composition of die material can be modified using high carbide former in addition to increasing the thermal transmission in the microstructure. Among other manufacturing processes, casting is the most feasible and low cost method to produce die. Despite being a cheaper option for die making, works need to be done to enhance the casting integrity for a sustainable lifecycle.

\section{ACKNOWLEDGEMENTS}

The authors would like to thank Universiti Malaysia Pahang for financial support under grant number GRS 140395.

\section{REFERENCES}

[1] Steinbeiss H, So H, Michelitsch T, Hoffmann H. Method for optimizing the cooling design of hot stamping tools. Production Engineering. 2007;1:149-55.

[2] Zhong-de S, Mi-lan Z, Chao J, Ying X, Wen-juan R. Basic study on die cooling system of hot stamping process. Advanced Technology of Design and Manufacture (ATDM 2010), International Conference on: IET; 2010. p. 1-4.

[3] Abdulhay B, Bourouga B, Dessain C. Experimental and theoretical study of thermal aspects of the hot stamping process. Applied Thermal Engineering. 2011;31:674-85.

[4] Ghiotti A, Sgarabotto F, Bruschi S. A novel approach to wear testing in hot stamping of high strength boron steel sheets. Wear. 2013;302:1319-26.

[5] Karbasian H, Tekkaya AE. A review on hot stamping. J Mater Process Tech. 2010;210:2103-18.

[6] Casas B, Latre D, Rodriguez N, Valls I. Tailor made tool materials for the present and upcoming tooling solutions in hot sheet metal forming. 1st International Conference on Hot Sheet Metal Forming of High Performance Steels, Luleå, Sweden, October2008. p. 22-4.

[7] Naganathan A, Penter L. Hot stamping. Sheet metal forming-Processes and applications, ASM international. 2012:134-56.

[8] Hu P, Ma N, Liu L-z, Zhu Y-g. Theories, methods and numerical technology of sheet metal cold and hot forming: analysis, simulation and engineering applications: Springer Science \& Business Media; 2012.

[9] Tisza M. MATERIAL DEVELOPMENTS IN SHEET METAL FORMING. 2013;6:79-88.

[10] Jhavar S, Paul C, Jain N. Causes of failure and repairing options for dies and molds: a review. Engineering Failure Analysis. 2013;34:519-35.

[11] Sandberg N. On the Machinability of High Performance Tool Steels. Acta Universitatis Upsaliensis Uppsala. 2012.

[12] Davis JR. Metals Handbook Desk Edition, 2nd Edition: ASM International; 1998.

[13] Cubberly WH, Baker H, Benjamin D, Unterweiser P, Kirkpatrick C, Knoll V, et al. Properties and selection: nonferrous alloys and pure metals. Metals Handbook. 1979;2:75. 
[14] Peet M, Hasan H, Bhadeshia H. Prediction of thermal conductivity of steel. Int J Heat Mass Tran. 2011;54:2602-8.

[15] Fuchs K. Hot-work tool steels with improved properties for die-casting applications. 6th International Tooling Conference2002. p. 15-22.

[16] Kheirandish S, Noorian A. Effect of niobium on microstructure of cast AISI H13 hot work tool steel. Journal of Iron and Steel Research, International. 2008;15:616.

[17] Angles IV. Process for setting the thermal conductivity of a steel, tool steel, in particular hot-work steel, and steel object. Google Patents; 2013.

[18] Sinha V, Spowart J. Influence of interfacial carbide layer characteristics on thermal properties of copper-diamond composites. J Mater Sci. 2013;48:1330-41.

[19] Shen X-Y, He X-B, Ren S-B, Zhang H-M, Qu X-H. Effect of molybdenum as interfacial element on the thermal conductivity of diamond/ $\mathrm{Cu}$ composites. Journal of Alloys and Compounds. 2012;529:134-9.

[20] Yang X, SONG Y-q, LIN C-g, Shun C, FANG Z-z. Effect of carbide formers on microstructure and thermal conductivity of diamond-Cu composites for heat sink materials. Transactions of Nonferrous Metals Society of China. 2009;19:1161-6.

[21] Angles IV. Method and device for producing a workpiece, particularly a shaping tool or a part of a shaping tool. Google Patents; 2009.

[22] Dourandish M, Simchi A. Study the sintering behavior of nanocrystalline 3YTZP/430L stainless-steel composite layers for co-powder injection molding. J Mater Sci. 2009;44:1264-74.

[23] Imran MK, Masood S, Brandt M, Bhattacharya S, Gulizia S, Jahedi M, et al. Thermal fatigue behavior of direct metal deposited H13 tool steel coating on copper alloy substrate. Surface and Coatings Technology. 2012;206:2572-80.

[24] Yuan J, Zhang K, Zhang X, Li X, Li T, Li Y, et al. Thermal characteristics of Mg$\mathrm{Zn}-\mathrm{Mn}$ alloys with high specific strength and high thermal conductivity. Journal of Alloys and Compounds. 2013;578:32-6.

[25] Al-Jamal O, Hinduja S, Li L. Characteristics of the bond in $\mathrm{Cu}-\mathrm{H} 13$ tool steel parts fabricated using SLM. CIRP Annals-Manufacturing Technology. 2008;57:239-42.

[26] Jae-Ho L, Jeong-Hwan J, Byeong-Don J, Hong-Sup Y, Young-Hoon M. Application of direct laser metal tooling for AISI H13 tool steel. Transactions of Nonferrous Metals Society of China. 2009;19:s284-s7.

[27] Schruff I, Schüler V, Spiegelhauer C. Advanced tool steels produced via spray forming. The Use of Tool Steels: Experience and Research. 2002;2:10-3.

[28] Balla VK, Bose S, Bandyopadhyay A. Laser surface modification of Al-4Cu$1 \mathrm{Mg}$ alloy for enhanced thermal conductivity. Opt Laser Eng. 2009;47:651-5.

[29] Spiegelhauer C. Industrial production of tool steels using the spray forming technology. The use of tool steels: Experience and research. 2002;2:1101-9. 